Article

\title{
Soil Biological Fertility and Bacterial Community Response to Land Use Intensity: A Case Study in the Mediterranean Area
}

\author{
Mohammad Yaghoubi Khanghahi *, Pasqua Murgese, Sabrina Strafella and Carmine Crecchio \\ Department of Soil, Plant and Food Sciences, University of Bari Aldo Moro, Via Amendola 165/a, 70125 Bari, \\ Italy; patty.murgese@libero.it (P.M.); sabrina.strafella.bio@gmail.com (S.S.); carmine.crecchio@uniba.it (C.C.) \\ * Correspondence: mohammad.yaghoubikhanghahi@uniba.it; Tel.: +39-080-5442854
}

Received: 24 October 2019; Accepted: 8 November 2019; Published: 10 November 2019

\begin{abstract}
The current study was performed to investigate the effects of three different long-term land use intensities on adjacent soil plots, namely a winter wheat field, a grass-covered vineyard, and a cherry farm, on soil biochemical, microbial, and molecular parameters. The results showed the maximum content of soil organic matter (SOM) and microbial biomass carbon (MBC) observed in the grass-covered vineyard. Basal respiration (BSR) and the cumulated respiration (CSR) after 25 days of incubation were significantly higher in the grass-covered vineyard and cherry farm, respectively (BSR $11.84 \mathrm{mg} \mathrm{CO}_{2}-\mathrm{C} \mathrm{kg}^{-1}$ soil d ${ }^{-1}$, CSR $226.90 \mathrm{mg} \mathrm{CO}_{2}-\mathrm{C} \mathrm{kg}^{-1}$ soil). Grass-covered vineyard showed the highest soil biological fertility index (BFI) score (20) and ranked in the class IV (good) of soil biological fertility. Cereal field and cherry farm had lower BFI scores and the corresponding BFI class was III (medium). In addition, the maximum ribosomal RNA copy number and the highest abundance of oligotrophic bacterial groups (25.52\% Actinobacteria, 3.45\% Firmicutes, and $1.38 \%$ Acidobacteria) were observed in the grass-covered vineyard. In conclusion, the grass-covered vineyard is a more conservative system and could have a large potential to improve total carbon storage in soil, mainly because of the cover crop residue management and the low soil perturbation through the no-tillage system.
\end{abstract}

Keywords: bacterial community structure; biological fertility index; land use; microbial biomass; microbial respiration; ribosomal RNA copy numbers

\section{Introduction}

One of the most important negative factors on Mediterranean ecosystems is the conversion of natural landforms into cropland and grassland, due to agricultural development [1]. Nearly $40 \%$ of Puglia (a typical Mediterranean region) lands have been converted to farmland for growing olives, table grapes, and almonds over recent centuries [2]. In addition, over $80 \%$ of Puglia lands, classified as agricultural land [3], have always been exposed to land degradation because of intensive management practices and land use change [4,5]. Land conversion has become a challenge in Puglia region, where lands are surrounded by soft carbonate rocks and hard calcareous stones [6,7]. However, for a short period of time, soil quality can be improved by the decomposition of rocks because of nutrients released into the soil, but over the long run, land degradation and ecosystem deterioration will occur, which may lead to the farmlands abandonment [2].

Many studies have been focused on examining soil chemical and physical parameters such as soil reaction $(\mathrm{pH})$, soil organic carbon (SOC), cation exchange capacity (CEC), electric conductivity (EC), aggregate stability, bulk density, and soil porosity [8,9]. On the other hand, a proposed minimum dataset for soil quality assessment as quantitative indicators is linked to physical, chemical, and 
biological parameters or a mix of physical and biological characteristics, such as soil texture, infiltration, and soil bulk density, water holding capacity, SOC, soil microbial biomass, and microbial activity, $\mathrm{pH}$ value, total organic carbon, and nitrogen $(\mathrm{N}), \mathrm{N}$ mineralized under aerobic condition, and extractable $\mathrm{N}$, phosphorus $(\mathrm{P})$, and potassium $(\mathrm{K})[10,11]$.

Therefore, a comprehensive indicator system is required to be used for soil monitoring among all types of biological indicators and biogeochemical cycles [12]. In this regard, the soil Biological Fertility Index (BFI) was introduced by Renzi et al. [13] according to some biochemical parameters of soil, including SOM, microbial biomass carbon (MBC), basal respiration at the last day of incubation (BSR), cumulated respiration during the incubation period (CSR), metabolic quotient $\left(\mathrm{qCO}_{2}\right)$, and mineralization quotient $(\mathrm{qM})$. It has already been reported that the BFI indicator may be more efficient than microbial biomass and activity alone and can be used to assess soil quality at varying levels of human disturbance [12,13].

There have been relatively limited researches dealing with the impacts of different types of land use intensities on microbial and biochemical soil properties in the Mediterranean-type ecosystems and extremely rarely addressed by ecological researchers in term of the application of precise indicators in complex Mediterranean mosaic landscapes $[12,14]$. Therefore, the present research aimed to investigate the effects of different land use intensities, which are frequently adopted in the agro-ecosystems of the Mediterranean area, on soil chemical, biochemical and microbial parameters. Three different long-term land use intensities on adjacent soil plots, recently converted from natural landform to farmland by rock fragmentation and intensive agricultural management, were investigated. Namely, soil plots were a winter wheat field (soil tillage, residues removal, integrated pest management, no irrigation, chemical fertilization), a grass-covered vineyard (no tillage, residues left on the field, integrated pest management, drip irrigation with continuous mixed chemical and organic fertilization), and a cherry farm (soil tillage, residues removal, drip irrigation with continuous chemical fertilization). Our hypothesis is that the long-term land use changes soil biological fertility, evaluated by the Biological Fertility Index (BFI) and composition and abundance of soil bacterial community.

\section{Materials and Methods}

The study was performed in a Mediterranean soil ecosystem in Puglia region, Italy (Figure 1) (Turi, located at $40^{\circ} 91^{\prime} \mathrm{N}, 17^{\circ} 04^{\prime} \mathrm{E}$, altitude of $247 \mathrm{~m}$ above the average of sea level, with long-term annual precipitation range from approximately $550 \mathrm{~mm}$ to $600 \mathrm{~mm}$ and annual temperature range from 4 to $30^{\circ} \mathrm{C}$ ) with Mediterranean climate conditions according to the Domarten classification.

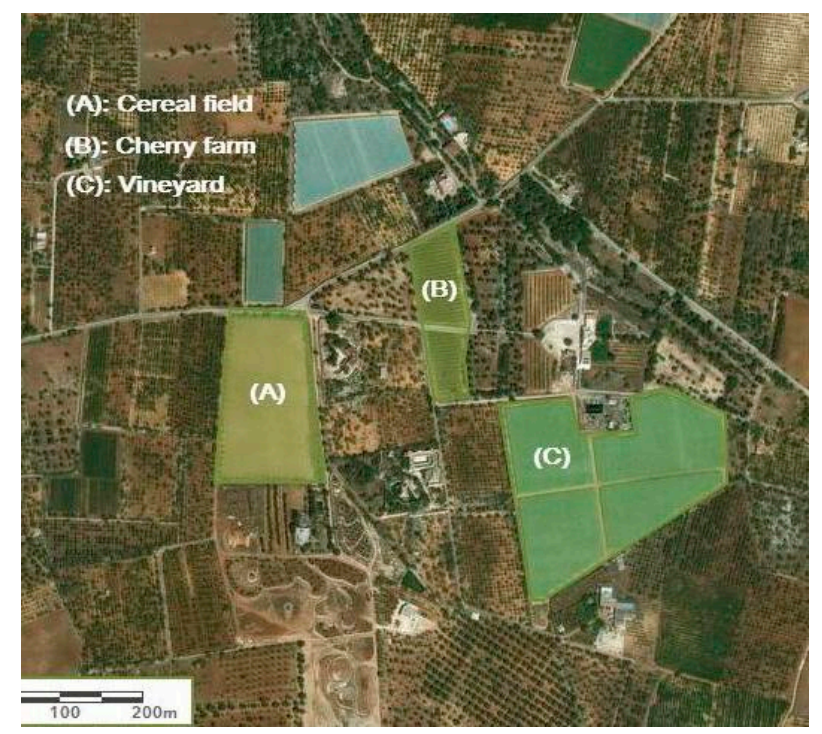

Figure 1. The area located at Turi in Puglia region, Southern Italy. 
Three land-use intensities, namely cereal field (winter wheat), grass-covered vineyard, and cherry farm plots, were compared in adjacent plots. The land use descriptions and management are presented in Table 1.

Table 1. Land use management.

\begin{tabular}{ccccc}
\hline Land Use & Area (Ha) & Cultivation History (Year) & Management & Irrigation and Fertilization \\
\hline Cereal field & 2.4 & 7 & $\begin{array}{c}\text { Soil tillage }(40 \mathrm{~cm}) \text {, residues removal } \\
\text { from the field, integrated pest } \\
\text { management, }\end{array}$ & $\begin{array}{c}\text { No irrigation (dryland } \\
\text { farming), chemical } \\
\text { fertilization before seeding }\end{array}$ \\
\hline $\begin{array}{c}\text { Grass-covered } \\
\text { vineyard }\end{array}$ & 4.9 & 10 & $\begin{array}{c}\text { No tillage, residues left on the field, } \\
\text { integrated pest management, }\end{array}$ & $\begin{array}{c}\text { Drip irrigation with } \\
\text { continuous mixed } \\
\text { fertilization } \\
\text { (chemical-organic) }\end{array}$ \\
\hline Cherry farm & 1.2 & 10 & $\begin{array}{c}\text { Soil tillage }(40 \mathrm{~cm}), \text { residues removal } \\
\text { from the farm, integrated pest } \\
\text { management }\end{array}$ & $\begin{array}{c}\text { Drip irrigation with } \\
\text { continuous chemical } \\
\text { fertilization }\end{array}$ \\
\hline
\end{tabular}

The area was a natural landform with carbonates, clay, and iron oxides accumulation in depth (Chromic and Calcic Luvisols) that has been converted to farmland by rock fragmentation and intensive agricultural practices about 10 years ago and cultivated continuously. The geological characteristics of the plots (Luvisols from limestone) are similar and typical for this region.

Three composite soil samples from each land use were taken randomly from the upper soil layer in June 2018. A minimum of five sub-samples were collected, mixed together on site and considered as a composite soil sample. Samplings were carried out at depth of $0-20 \mathrm{~cm}$, since the maximum microbial biomass is devoted to the upper soil horizons [15] and microbial activity is sensitive to changed land uses [16]. The fraction passing a $2 \mathrm{~mm}$ sieve was transported refrigerated at $4{ }^{\circ} \mathrm{C}$.

\subsection{Measurements}

Soil $\mathrm{pH}$ was measured in an aqueous matrix in 1:2.5 soil: water suspension [17] using $\mathrm{pH}$ meter (XS Instruments $\mathrm{pH}$ 50, Carpi, Italy), soil texture according to the USDA classification [18] by the relative amounts of sand, silt, and clay in the fine earth fraction includes all soil particles that are less than $2 \mathrm{~mm}$. The Walkley and Black [19] method was performed to measure total soil organic carbon (SOC) and the van Bemmelen factor $(=1.724)$ was used to calculate the amount of soil organic matter (SOM) with the following equation [20]:

$$
\mathrm{SOM}=\mathrm{SOC} \times 1.724
$$

\subsection{Soil Microbial Biomass}

The chloroform fumigation extraction method [21] was used to estimate the microbial biomass carbon (MBC). In details, the air-dried soil was pre-incubated for five days at $30^{\circ} \mathrm{C}$ in open glass jars at field capacity. Three replicates of each soil $(12.5 \mathrm{~g})$ were fumigated with free ethanol chloroform for 24 $\mathrm{h}$ in vacuum desiccators at dark condition, and other three replicates were not fumigated as blank. Both the fumigated and non-fumigated soil samples were extracted with $0.5 \mathrm{M} \mathrm{K}_{2} \mathrm{SO}_{4}$ for $30 \mathrm{~min}$ and the resulting extracts were filtered. Potassium dichromate method [21] was used to measure MBC in filtrates.

\subsection{Microbial Respiration}

Soil microbial respiration was measured according to Isermeyer [22]. Twenty-five-gram soil samples were incubated in closed glass jars under dark conditions at field capacity and $30^{\circ} \mathrm{C}$. The $\mathrm{CO}_{2}$ evolved was trapped by $0.2 \mathrm{~N} \mathrm{NaOH}$ and measured by titration of the excess $\mathrm{NaOH}$ with $0.2 \mathrm{~N} \mathrm{HCl}$. The jars without soil maintained at the same way served as a $\mathrm{CO}_{2}$ blank. The difference of consumed volume of $\mathrm{HCl}$ between the samples and the blank in titration was considered to estimate the amount of $\mathrm{CO}_{2}$ evolution by soil microorganisms. Cumulated microbial respiration (CSR) is the respiration 
rate during 25 days of incubation period in $\mathrm{mg} \mathrm{CO}_{2}-\mathrm{C} \mathrm{kg}^{-1}$ soil. Basal respiration rate (BSR) is the respiration at the last day of incubation (The 25th day) expressed in $\mathrm{mg} \mathrm{CO}_{2}-\mathrm{C} \mathrm{kg}^{-1}$ soil d $\mathrm{d}^{-1}$.

The microbial metabolic quotient $\left(\mathrm{qCO}_{2}\right)$ indicates the amount of $\mathrm{CO}_{2}-\mathrm{C}$ produced per unit $\mathrm{MBC}$

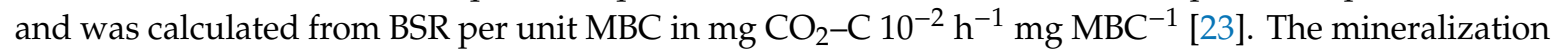
quotient (qM) is expressed in \% and calculated as the ratio of the CSR to SOC. The qM represents the efficiency of microflora to metabolize the soil organic carbon [24]. The efficiency of microbes to decompose organic carbon (CUE) was estimated as the ratio of microbial biomass carbon to soil organic carbon [25].

\subsection{Biological Fertility Index}

The Biological Fertility Index (BFI) is a comprehensive indicator by composing six biological variables, such as SOM, BSR, CSR, $\mathrm{MBC}, \mathrm{qCO}_{2}$, and $\mathrm{qM}$. Five intervals of values were set for each parameter, and scores increasing from 1 to 5 were assigned to each interval (Table 2) based on the available evidences from previous research [13]. The algebraic sum of scores for all the parameters providing the proposed classes of biological fertility are shown in Table 2

Table 2. Scores of the intervals of values for the different parameters.

\begin{tabular}{|c|c|c|c|c|c|}
\hline \multirow{2}{*}{ Parameters } & \multicolumn{5}{|c|}{ Scores } \\
\hline & 1 & 2 & 3 & 4 & 5 \\
\hline \multirow{2}{*}{ Soil organic matter, SOM (\%) } & \multirow[t]{2}{*}{$<1.0$} & $\geq 1.0$ & $>1.5$ & $>2.0$ & \multirow[t]{2}{*}{$>3.0$} \\
\hline & & $\leq 1.5$ & $\leq 2.0$ & $\leq 3.0$ & \\
\hline \multirow{2}{*}{$\begin{array}{l}\text { Basal soil respiration, BSR } \\
\left(\mathrm{mg} \mathrm{CO}_{2}-\mathrm{C} \mathrm{kg}^{-1} \text { soil d }{ }^{-1}\right)\end{array}$} & \multirow[t]{2}{*}{$<5$} & $\geq 5$ & $>10$ & $>15$ & \multirow[t]{2}{*}{$>20$} \\
\hline & & $\leq 10$ & $\leq 15$ & $\leq 20$ & \\
\hline \multirow{2}{*}{$\begin{array}{l}\text { Cumulative soil respiration, CSR } \\
\left(\mathrm{mg} \mathrm{CO}_{2}-\mathrm{C} \mathrm{kg}^{-1} \text { soil }\right)\end{array}$} & \multirow[t]{2}{*}{$<100$} & $\geq 100$ & $>250$ & $>400$ & \multirow[t]{2}{*}{$>600$} \\
\hline & & $\leq 250$ & $\leq 400$ & $\leq 600$ & \\
\hline \multirow{2}{*}{$\begin{array}{l}\text { Microbial biomass carbon, MBC } \\
\left.\text { (mg C kg }{ }^{-1} \text { soil }\right)\end{array}$} & \multirow[t]{2}{*}{$<100$} & $\geq 100$ & $>200$ & $>300$ & \multirow[t]{2}{*}{$>400$} \\
\hline & & $\leq 200$ & $\leq 300$ & $\leq 400$ & \\
\hline \multirow{2}{*}{ 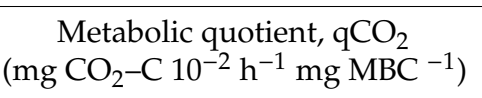 } & \multirow[t]{2}{*}{$\geq 0.4$} & $\geq 0.4$ & $<0.3$ & $<0.2$ & \multirow[t]{2}{*}{$<0.1$} \\
\hline & & $\leq 0.3$ & $\geq 0.2$ & $\geq 0.1$ & \\
\hline \multirow{2}{*}{ Mineralization quotient, qM (\%) } & \multirow[t]{2}{*}{$<1.0$} & $\geq 1$ & $>2$ & $>3$ & \multirow[t]{2}{*}{$>4$} \\
\hline & & $\leq 2$ & $\leq 3$ & $\leq 4$ & \\
\hline \multicolumn{6}{|c|}{ Classes of the Biological Fertility Index (BFI) } \\
\hline \multirow{2}{*}{ Fertility class } & $\mathrm{I}$ & II & III & IV & V \\
\hline & Stress & Pre-stress (alarm) & Medium & Good & High \\
\hline BFI scores sum & 6 & $7-12$ & $13-18$ & $19-24$ & $25-30$ \\
\hline
\end{tabular}

\subsection{Soil DNA Extraction}

The FastDNA ${ }^{\circledR}$ SPIN Kit for Soil (MP Biomedicals, Solon, CA, USA) was used for DNA extraction. Briefly, $0.5 \mathrm{~g}$ of soil was added into Lysing Matrix E tubes, and the samples were homogenized in a FastPrep ${ }^{\circledR}$ at setting $6.0 \mathrm{~m} \mathrm{~s}^{-1}$ for $40 \mathrm{~s}$. All extraction steps were performed according to the manufacturer's instructions for kit. Nucleic acid concentration was evaluated using a Nanodrop spectrophotometer (ND-1000, EuroClone, Milan, Italy).

\subsection{Real-Time Quantitative PCR Analysis (qPCR)}

qPCR was performed in triplicate to evaluate bacterial 16S rRNA gene copy numbers using an Applied Biosystems 7500 detection system (Applied Biosystems, Foster City, CA, USA) with 341 primer pairs, forward (5'-CCTACGGGNGGCWGCAG-3') and 785 primer pairs, reverse (5'-GACTACHVGGGTATCTA ATCC-3') [26]. The reaction mixture $(20 \mu \mathrm{L})$ and amplification conditions 
were performed based on the methods of Pascazio et al. [27]. Reference strain DNA of Azospirillum irakense [28] was used to create the standard curve and the gene copy number in the samples was calculated using the regression equation that related the cycle threshold $(\mathrm{Ct})$ value to the number of copies in the standard curve [29].

\subsection{Analyses of $16 S$ rRNA Gene Sequence, Species Richness and Diversity}

Aliquots of the extracted DNA were sent to the IGA Technology Service in Udine (Italy) for metagenomic analyses; the sequencing was performed through the MiSeq Illumina system platform. QIIME software (version 1.9.1) was used to perform bacterial community analysis as fully described by Kuczynski et al. [30]. There were two amplification steps in the library workflow: an initial PCR amplification using locus specific PCR primers and a subsequent amplification that integrates relevant flow-cell binding domains and unique indices (NexteraXT Index Kit, FC-131-1001/FC-131-1002). This method was used to amplify the variable V3 and V4 regions of the 16S rRNA gene aiming to characterize bacterial community compositions. Operational taxonomic units (OTUs) were identified using a cut-off of $97 \%$ similarity. Singletons, non-bacterial OTUs were removed, and the OTU abundance levels were normalized based on the sample with the least number of sequences.

To estimate the bacterial $\alpha$-diversity, CHAO1, Shannon and Simpson indices and good-coverage were calculated using the QIIME software based on 10,000 sequences per sample. Rarefaction curves endpoints and normalization of counts for diversity analysis was set to $50 \%$ of the target sequencing coverage (i.e., for 100,000 fragments a cutoff of 50,000 fragments were applied). Bacterial taxonomic assignment was conducted using the Ribosomal Database Project (RDP) Naïve Bayesian classifier and reference database with a minimum confidence threshold of $50 \%$.

\subsection{Statistical Analysis}

All statistical analyses including the least significant difference (LSD) test, performed to compare the differences among parameters means at a 5\% level, correlation (Pearson, two-tailed), regression (multiple linear regression, backward method) and cluster (Ward's method) analysis were done using SPSS software (Statistical Product and Service Solutions, version 16, IBM, New York, NY, USA).

\section{Results}

\subsection{Chemical and Microbial Parameters}

Results of the soil chemical parameters and microbial activity in different land use are summarized in Table 3. There was no difference among the three land uses in terms of soil $\mathrm{pH}$ and texture. However, cherry farm soil had a slightly lower sand and silt content and higher $\mathrm{pH}$ than the other soils. The results showed that soil organic carbon (SOC) of the samples from grass-covered vineyard and from cereal field was significantly greater than that from the cherry farm. In particular, SOC was $1.82 \%$ and $1.69 \%$ in the grass-covered vineyard and cereal field, respectively, which was 1.33 and 1.24 times more than that in the cherry field (Table 3). Accordingly, the maximum soil organic matter (SOM) was recorded in grass-covered vineyard, while the lowest was found in cherry farm (3.13\% and $2.35 \%$, respectively). The maximum values of microbial biomass (MBC) was observed in the grass-covered vineyard soil (201.92 $\mu \mathrm{g} \mathrm{C} \mathrm{g}^{-1}$ soil), which was about $2.45 \%$ and $8.29 \%$ more than that in cereal and cherry farm soils, respectively. Basal soil respiration (BSR) and the cumulated respiration (CSR) after 25 days of incubation were significantly higher in grass-covered vineyard and cherry farm, respectively (BSR $11.84 \mathrm{mg} \mathrm{CO}_{2}-\mathrm{C} \mathrm{kg}^{-1}$ soil d ${ }^{-1}$, CSR $226.90 \mathrm{mg} \mathrm{CO}_{2}-\mathrm{C} \mathrm{kg}^{-1}$ soil) than in the cereal field (BSR $9.73 \mathrm{mg}$ $\mathrm{CO}_{2}-\mathrm{C} \mathrm{kg}^{-1}$ soil d ${ }^{-1}, \mathrm{CSR} 153.91 \mathrm{mg} \mathrm{CO}-\mathrm{C} \mathrm{kg}^{-1}$ soil). The highest and significantly different value of efficiency of microbes to decompose organic matter (CUE) was found in cherry farm (138.08 $\mu \mathrm{g} \mathrm{C}$ $\mathrm{g}^{-1}$ soil). The highest amount of metabolic quotient $\left(\mathrm{qCO}_{2}\right)$ were detected in grass-covered vineyard

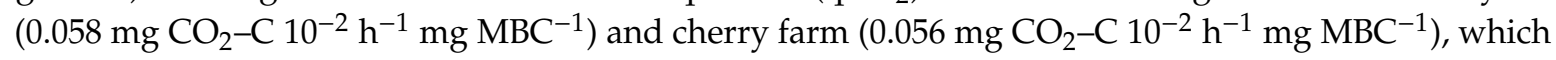
were about $16 \%$ and $12 \%$ higher than that in the cereal field. We also found statistically significant 
differences among land uses in term of carbon mineralization quotient (qM). These values varied from $0.91 \%$ in the cereal field to $1.66 \%$ in the cherry farm.

Table 3. Chemical and microbial parameters under different land use.

\begin{tabular}{|c|c|c|c|c|}
\hline \multirow{2}{*}{ Parameter } & \multirow{2}{*}{ Unit } & \multicolumn{3}{|c|}{ Land Use } \\
\hline & & Cereal Field & Grass-Covered Vineyard & Cherry Farm \\
\hline Soil pH & & $7.95 \pm 0.04$ & $7.95 \pm 0.01$ & $7.98 \pm 0.04$ \\
\hline Soil texture & & & Sandy Clay Loam & \\
\hline SOC & $\%$ & $1.69 \pm 0.17 \mathrm{a}$ & $1.82 \pm 0.13 \mathrm{a}$ & $1.36 \pm 0.11 b$ \\
\hline SOM & $\%$ & $2.91 \pm 0.29 \mathrm{a}$ & $3.13 \pm 0.22 \mathrm{a}$ & $2.35 \pm 0.19 b$ \\
\hline MBC & $\mu \mathrm{gC} \mathrm{g}^{-1}$ soil & $197.08 \pm 18.76 \mathrm{a}$ & $201.92 \pm 20.81 \mathrm{a}$ & $186.45 \pm 14.19 b$ \\
\hline CUE & $\mu g \mathrm{Cg}^{-1}$ soil & $117.06 \pm 1.14 \mathrm{~b}$ & $110.53 \mathrm{~b} \pm 4.96$ & $138.08 \mathrm{a} \pm 12.98$ \\
\hline BSR & $\mathrm{mg} \mathrm{CO} \mathrm{CO}_{2}-\mathrm{C} \mathrm{kg}^{-1}$ soil d ${ }^{-1}$ & $9.73 \pm 0.87 b$ & $11.84 \pm 0.66 \mathrm{a}$ & $10.51 \pm 1.11 \mathrm{ab}$ \\
\hline CSR & $\mathrm{mg} \mathrm{CO} 2-\mathrm{C} \mathrm{kg}^{-1}$ soil & $153.91 \pm 10.77 \mathrm{~b}$ & $214.49 \pm 13.69 \mathrm{a}$ & $226.90 \pm 18.88 \mathrm{a}$ \\
\hline $\mathrm{qCO}_{2}$ & $\mathrm{mg} \mathrm{CO} 2-\mathrm{C} 10^{-2} \mathrm{~h}^{-1} \mathrm{mg} \mathrm{MBC}^{-1}$ & $0.050 \pm 0.004 \mathrm{~b}$ & $0.058 \pm 0.005 \mathrm{a}$ & $0.056 \mathrm{a} \pm 0.004$ \\
\hline $\mathrm{qM}$ & $\%$ & $0.91 \pm 0.08 c$ & $1.17 \pm 0.10 \mathrm{~b}$ & $1.66 \pm 0.15 \mathrm{a}$ \\
\hline Nucleic acid concentration & $\mathrm{ng} \mu \mathrm{L}^{-1} 0.5 \mathrm{~g}^{-1}$ & $154.8 \pm 6.01 \mathrm{~b}$ & $160.6 \pm 5.49 \mathrm{a}$ & $143.7 \pm 5.94 \mathrm{c}$ \\
\hline 16S rRNA- CN & $\mathrm{g}^{-1} \mathrm{DS}$ & $8.06 \pm 1.28 \times 10^{7} \mathrm{a}$ & $1.82 \pm 0.51 \times 10^{7} \mathrm{c}$ & $5.18 \pm 0.32 \times 10^{7} \mathrm{~b}$ \\
\hline
\end{tabular}

Means ( \pm standard error) of each parameter followed by a similar letter are not significantly different based on the least significant difference (LSD) test at the $5 \%$ probability level. SOC: total organic carbon, SOM: total organic matter, MBC: microbial biomass C, CUE: microbial carbon use efficiency, BSR: basal soil respiration, CSR: cumulative soil respiration, $\mathrm{qCO}_{2}$ : metabolic quotient, qM: mineralization quotient, $16 \mathrm{~S}$ rRNA- $\mathrm{CN}$ : Bacterial $16 \mathrm{~S}$ rRNA gene copy numbers.

Regression of cubic equation models significantly fitted $(P<0.01)$ correlations between microbial respiration rate and time period of incubation. The coefficients of determination $\left(R^{2}\right)$ of the equations were $0.98,0.95$, and 0.99 in the cereal field, grass-covered vineyard, and cherry farm, respectively (Table 4, Figure 2).

Table 4. Regression coefficient for determining the relationship between the microbial respiration rates in different land use after an incubation period of 25 days.

\begin{tabular}{lcccccc}
\hline Land Use & Equation & R Square & Constant & b1 & b2 & b3 \\
\hline Cereal field & Cubic & $0.98^{* *}$ & 18.28 & 1.57 & -0.18 & 0.004 \\
Grass-covered vineyard & Cubic & $0.95^{* *}$ & 38.79 & -0.75 & -0.12 & 0.004 \\
Cherry farm & Cubic & $0.99^{* *}$ & 61.92 & -8.11 & 0.44 & -0.008 \\
\hline
\end{tabular}

** corresponds to significance at $p<0.01$.

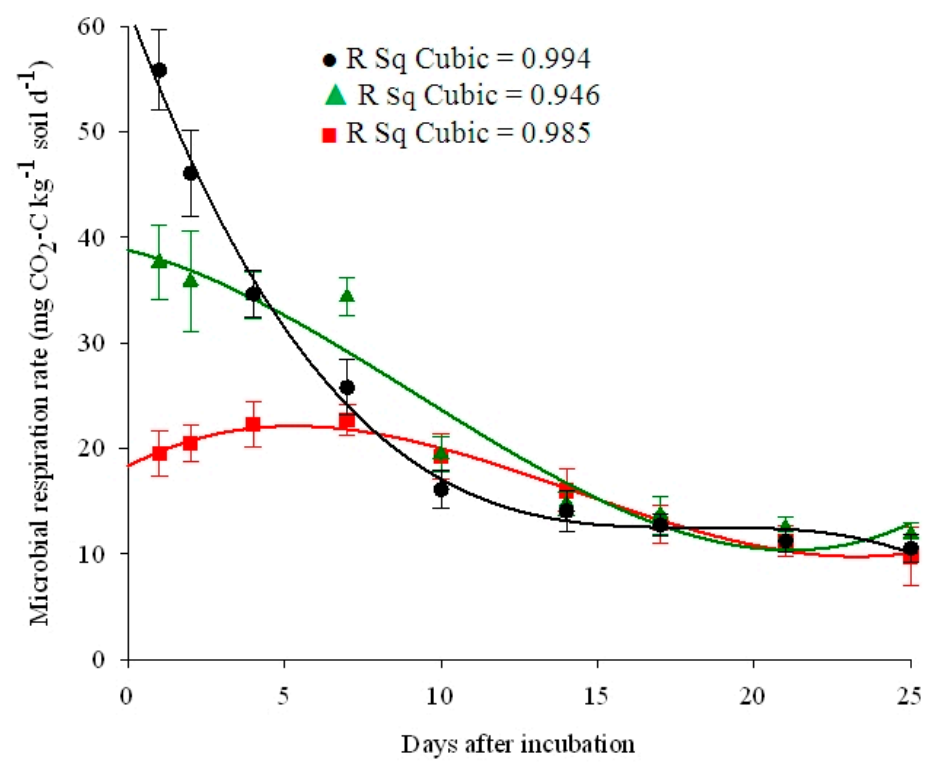

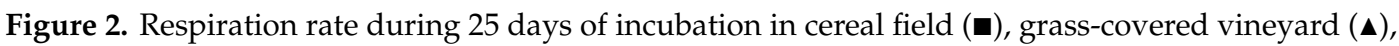
and cherry farm $(\bullet)$. 


\subsection{Soil Biological Fertility Index}

The soil Biological Fertility Index (BFI) was calculated to determine the overall effect of land-use systems on soil quality. The BFI results and the average scores of the parameters with respect to land use are given in Table 5. Grass-covered vineyard showed the highest BFI score (20) and ranked in class IV (good) of soil biological fertility, which is assumed to be a sustainable ecosystem for the long-term. The other two managements (cereal field and cherry farm) had lower BFI scores (16 and 18, respectively), corresponding to a BFI of class III (medium) (Table 5).

Table 5. Scores of the soil parameters and biological fertility index for the different land uses.

\begin{tabular}{lcccccccc}
\hline Land Use & SOM & BSR & CSR & MBC & $\mathbf{q C O}_{2}$ & $\mathbf{q M}$ & BFI Score & BFI Class \\
\hline Cereal field & 4 & 2 & 2 & 2 & 5 & 1 & 16 & III (medium) \\
Grass-covered vineyard & 5 & 3 & 2 & 3 & 5 & 2 & 20 & IV (good) \\
Cherry farm & 4 & 3 & 2 & 2 & 5 & 2 & 18 & III (medium) \\
\hline
\end{tabular}

SOM: total organic matter, MBC: microbial biomass C, BSR: basal soil respiration, CSR: cumulative soil respiration, $\mathrm{qCO}_{2}$ : metabolic quotient, $\mathrm{qM}$ : mineralization quotient, BFI: biological fertility index.

The multiple linear regressions were used to explain which of the biological parameters could be more useful to predict the BFI under different land uses. In order to achieve this purpose, backward elimination method was used, and the results are shown in Table 6. Accordingly, SOM and CSR were identified as two independent variables which had most impact on BFI (dependent variable). The rankings of the parameters were $\mathrm{SOM}>\mathrm{CSR}>\mathrm{qM}>\mathrm{qCO}_{2}>\mathrm{BSR}>\mathrm{MBC}$. This multiple linear regression model with two explanatory variables (SOM and CSR) had an $\mathrm{R}^{2}$ of 0.916 . Therefore, $91.6 \%$ of the variation in\%BFI can be explained by this model and variables (Table 6).

Table 6. Multiple linear regressions (backward method) among BFI (dependent variable) and six biological variables (independent variables) under three land uses.

\begin{tabular}{|c|c|c|c|c|c|}
\hline Model & Independent Variables & \multicolumn{2}{|c|}{ Standardized Coefficients (Beta) } & $\mathbf{t}$ & Significance Level \\
\hline \multirow{7}{*}{1} & (Constant) & & & 1.059 & 0.401 \\
\hline & SOM & & & 0.932 & 0.450 \\
\hline & BSR & & & 0.603 & 0.608 \\
\hline & CSR & & & 1.352 & 0.309 \\
\hline & MBC & & & -0.550 & 0.638 \\
\hline & $\mathrm{qCO}_{2}$ & & & -0.625 & 0.596 \\
\hline & $\mathrm{qM}$ & & & -0.980 & 0.430 \\
\hline \multirow{6}{*}{2} & (Constant) & & & 3.756 & 0.033 \\
\hline & SOM & & & 1.181 & 0.323 \\
\hline & BSR & & & 0.372 & 0.735 \\
\hline & CSR & & & 2.061 & 0.131 \\
\hline & $\mathrm{qCO}_{2}$ & & & -0.454 & 0.680 \\
\hline & $\mathrm{qM}$ & & & -1.035 & 0.377 \\
\hline \multirow{5}{*}{3} & (Constant) & & & 4.827 & 0.008 \\
\hline & $\mathrm{SOM}$ & & & 2.782 & 0.050 \\
\hline & CSR & & & 3.835 & 0.019 \\
\hline & $\mathrm{qCO}_{2}$ & & & -0.363 & 0.735 \\
\hline & $\mathrm{qM}$ & & & -1.229 & 0.286 \\
\hline \multirow{4}{*}{4} & (Constant) & & & 5.318 & 0.003 \\
\hline & SOM & & & 3.035 & 0.029 \\
\hline & CSR & & & 4.269 & 0.008 \\
\hline & $\mathrm{qM}$ & & & -1.544 & 0.183 \\
\hline \multirow{3}{*}{5} & (Constant) & & & 5.703 & 0.001 \\
\hline & SOM & & & 8.765 & 0.000 \\
\hline & CSR & & & 5.761 & 0.001 \\
\hline \multicolumn{6}{|c|}{ Model Summary } \\
\hline Model & $\mathbf{R}$ & $\mathbf{R}^{2}$ & Adjusted $\mathbf{R}^{2}$ & \multicolumn{2}{|c|}{ Std. Error of the Estimate } \\
\hline 1 & 0.983 & 0.966 & 0.863 & & 0.46969 \\
\hline 2 & 0.980 & 0.961 & 0.895 & & 0.41147 \\
\hline 3 & 0.979 & 0.959 & 0.918 & & 0.36447 \\
\hline 4 & 0.978 & 0.957 & 0.932 & & 0.33132 \\
\hline 5 & 0.968 & 0.937 & 0.916 & & 0.36752 \\
\hline
\end{tabular}

SOM: total organic matter, MBC: microbial biomass C, BSR: basal soil respiration, CSR: cumulative soil respiration, $\mathrm{qCO}_{2}$ : metabolic quotient, $\mathrm{qM}$ : mineralization quotient. 


\subsection{Nucleic Acid Concentration}

The amount of nucleic acid was affected by different land use intensities. The highest amount of nucleic acid was extracted from grass-covered vineyard soil samples $\left(160.6 \mathrm{ng} \mu \mathrm{L}^{-1} 0.5 \mathrm{~g}^{-1}\right)$ and the lowest value from cherry farm soil samples $\left(143.7 \mathrm{ng} \mu \mathrm{L}^{-1} 0.5 \mathrm{~g}^{-1}\right)$ (Table 3).

\subsection{Bacterial Quantification}

Bacterial quantification was performed on DNA extracts using a quantitative real-time polymerase chain reaction (qPCR) analysis. The bacterial ribosomal RNA gene copy numbers ranged from 1.82 to $8.06 \times 10^{7} \mathrm{~g}^{-1}$ soil. Land use intensities had a significant effect on the ribosomal gene abundances, which was higher in the cereal field than that in the DNA extracted from grass-covered vineyard and cherry farm soils (Table 3).

\subsection{Correlation Coefficients among Parameters}

The Pearson correlation coefficients showed that there were significant positive correlations between MBC and SOM, BSR and $\mathrm{qCO}_{2}, \mathrm{CSR}$ and $\mathrm{qM}(p<0.05)$, and negative correlations between $\mathrm{MBC}$ and $\mathrm{qCO}_{2}(p<0.05)$ and $\mathrm{qM}$ and $\mathrm{SOM}(p<0.05)$ is soil under different managements. In addition, there was a significant positive correlation between the nucleic acid concentration and SOM and MBC in soil samples under different land uses. We observed a negative correlation $(p<0.05)$ between nucleic acid concentration and qM. A significantly $(p<0.05)$ negative correlation was also observed between the rRNA gene copy numbers and soil microbial respiration (both basal and cumulative respirations) (Table 7).

Table 7. Pearson correlation coefficients $(r)$ between biological and molecular variables under different land uses $(n=9)$.

\begin{tabular}{|c|c|c|c|c|c|c|c|c|}
\hline Parameters & SOM & BSR & CSR & MBC & $\mathrm{qCO}_{2}$ & $\mathrm{qM}$ & Nucleic Acid Concentration & 16S rRNA- CN \\
\hline SOM & 1 & & & & & & & \\
\hline BSR & $0.25^{\mathrm{ns}}$ & 1 & & & & & & \\
\hline CSR & $-0.27^{\mathrm{ns}}$ & $0.60^{\mathrm{ns}}$ & 1 & & & & & \\
\hline $\mathrm{qCO}_{2}$ & $-0.41^{\mathrm{ns}}$ & $0.68 *$ & $0.44^{\mathrm{ns}}$ & $-0.79 *$ & 1 & & & \\
\hline $\mathrm{qM}$ & $-0.76^{*}$ & $0.27^{\mathrm{ns}}$ & $0.76 *$ & $-0.58^{\mathrm{ns}}$ & $0.59^{\text {ns }}$ & 1 & & \\
\hline Nucleic acid concentration & $0.91 * *$ & $0.31^{\mathrm{ns}}$ & $-0.21^{\mathrm{ns}}$ & $0.68 *$ & $-0.33^{\mathrm{ns}}$ & $-0.69 *$ & 1 & \\
\hline $16 \mathrm{~S}$ rRNA- CN & $-0.15^{\text {ns }}$ & $-0.71 *$ & $-0.68 *$ & $-0.00^{\mathrm{ns}}$ & $-0.45^{\mathrm{ns}}$ & $-0.25^{\mathrm{ns}}$ & $-0.27^{\mathrm{ns}}$ & 1 \\
\hline
\end{tabular}

${ }^{*}$ and ${ }^{* *}$ : Significant at $p<0.05$ and $p<0.01$ levels, respectively. ns: not significant. SOM: total organic matter, MBC: microbial biomass C, BSR: basal respiration, CSR: cumulative soil respiration, $\mathrm{qCO}_{2}$ : metabolic quotient, $\mathrm{qM}$ : mineralization quotient, 16S rRNA CN: Bacterial 16S rRNA gene copy numbers.

\subsection{Bacterial $\alpha$ Diversity and Community Composition}

A total of 479,160 high-quality sequences were detected with a 300-bp read length. The minimum Good's coverage value was 0.99 according to the similarity cut-off of $97 \%$, meaning that a sufficient number of reads were obtained to evaluate bacterial diversity. There were no statistically significant differences among land uses in term of bacterial $\alpha$-diversity (Table 8), although the grass-covered vineyard non-significantly increased $\mathrm{CHAO} 1$ and Shannon indices, as compared to the other ecosystems.

Table 8. Estimation of $\alpha$-diversity indexes for bacterial communities under different land uses (sequence count: 10,000).

\begin{tabular}{lllll}
\hline Land Use & CHAO1 & Simpson & Shannon & Goods-Coverage \\
\hline Cherry farm & $4882.3 \pm 108.95 \mathrm{a}$ & $0.85 \pm 0.00 \mathrm{a}$ & $9.93 \pm 0.8 \mathrm{a}$ & $0.99 \pm 0.00 \mathrm{a}$ \\
Cereal field & $4558.8 \pm 97.04 \mathrm{a}$ & $0.87 \pm 0.00 \mathrm{a}$ & $9.84 \pm 0.05 \mathrm{a}$ & $0.99 \pm 0.00 \mathrm{a}$ \\
Grass-covered vineyard & $4973.2 \pm 61.94 \mathrm{a}$ & $0.85 \pm 0.00 \mathrm{a}$ & $10.14 \pm 0.4 \mathrm{a}$ & $0.99 \pm 0.00 \mathrm{a}$ \\
\hline
\end{tabular}

Means ( \pm standard error) in each column followed by similar letter are not significantly different based on the least significant difference (LSD) test at $5 \%$ probability level. 
Relative abundances (\%) of bacteria at the phylum ( $>1 \%)$ and family levels $(>2 \%)$ are presented in Table 9. Proteobacteria was the dominant phylum in all soil samples of land uses, which varied from $26.38 \%$ and $26.43 \%$ (in the cherry farm and grass-covered vineyard, respectively) to $29.29 \%$ (in the cereal field) of the total sequences, followed by Actinobacteria $(22.88 \%-25.51 \%)$ and Bacteroidetes $(6.88 \%-8.82 \%)$. The maximum abundance of Actinobacteria, Firmicutes and Acidobacteria was detected in the samples of the grass-covered vineyard. Moreover, the abundance of Planctomycetes and Gemmatimonadetes were also higher in the cherry farm than those in other ecosystems.

Table 9. Relative abundance of (A) bacterial phyla (relative abundance $>1 \%$ ) and (B) families (relative abundance $>2 \%$ ) under different land uses.

\begin{tabular}{|c|c|c|c|c|}
\hline \multicolumn{2}{|l|}{ (A) } & \multicolumn{3}{|c|}{ Land Use } \\
\hline \multicolumn{2}{|c|}{ Phylum } & Cherry Farm (\%) & Cereal Field (\%) & Grass-Covered Vineyard (\%) \\
\hline \multicolumn{2}{|c|}{ Proteobacteria } & $26.38 \pm 0.58 b$ & $29.29 \pm 0.79 a$ & $26.43 \pm 0.23 b$ \\
\hline \multicolumn{2}{|c|}{ Actinobacteria } & $22.88 \pm 0.25 b$ & $23.71 \pm 1.05 b$ & $25.51 \pm 1.41 \mathrm{a}$ \\
\hline \multicolumn{2}{|c|}{ Bacteroidetes } & $7.58 \pm 0.99 \mathrm{a}$ & $8.82 \pm 0.46 \mathrm{a}$ & $6.88 \pm 0.35 a$ \\
\hline \multicolumn{2}{|c|}{ Planctomycetes } & $5.03 \pm 0.19 \mathrm{a}$ & $4.13 \pm 0.21 \mathrm{ab}$ & $3.98 \pm 0.28 \mathrm{~b}$ \\
\hline \multicolumn{2}{|c|}{ Verrucomicrobia } & $4.67 \pm 0.11 \mathrm{ab}$ & $5.28 \pm 0.51 \mathrm{a}$ & $3.09 \pm 0.11 b$ \\
\hline \multicolumn{2}{|c|}{ Chloroflexi } & $4.33 \pm 0.66 \mathrm{a}$ & $3.85 \pm 0.27 \mathrm{a}$ & $3.89 \pm 0.23 \mathrm{a}$ \\
\hline \multicolumn{2}{|c|}{ Firmicutes } & $3.25 \pm 0.39 \mathrm{ab}$ & $2.32 \pm 0.20 \mathrm{~b}$ & $3.45 \pm 0.14 \mathrm{a}$ \\
\hline \multicolumn{2}{|c|}{ Gemmatimonadetes } & $2.00 \pm 0.04 \mathrm{a}$ & $1.31 \pm 0.05 \mathrm{c}$ & $1.64 \pm 0.10 \mathrm{~b}$ \\
\hline \multicolumn{2}{|c|}{ Acidobacteria } & $1.23 \pm 0.07 \mathrm{~b}$ & $0.95 \pm 0.03 c$ & $1.38 \pm 0.02 \mathrm{a}$ \\
\hline \multicolumn{5}{|l|}{ (B) } \\
\hline Phylum & Family & Cherry Farm (\%) & Cereal Field (\%) & Grass-Covered Vineyard (\%) \\
\hline Actinobacteria & Rubrobacteraceae & $7.20 \pm 0.35 b$ & $6.09 \pm 0.27 b$ & $8.68 \pm 0.28 \mathrm{a}$ \\
\hline Proteobacteria & Bradyrhizobiaceae & $2.33 \pm 0.29 \mathrm{a}$ & $2.56 \pm 0.08 \mathrm{a}$ & $2.78 \pm 0.13 \mathrm{a}$ \\
\hline Firmicutes & Bacillaceae & $2.10 \pm 0.31 \mathrm{a}$ & $1.23 \pm 0.14 b$ & $2.02 \pm 0.16 \mathrm{a}$ \\
\hline Actinobacteria & Solirubrobacteraceae & $2.56 \pm 0.58 \mathrm{a}$ & $1.87 \pm 0.02 \mathrm{~b}$ & $2.42 \pm 0.19 \mathrm{a}$ \\
\hline Bacteroidetes & Chitinophagaceae & $2.75 \pm 0.24 b$ & $2.81 \pm 0.02 \mathrm{~b}$ & $3.87 \pm 0.32 \mathrm{a}$ \\
\hline Planctomycetes & Gemmataceae & $2.55 \pm 0.04 \mathrm{a}$ & $1.26 \pm 0.10 \mathrm{~b}$ & $1.61 \pm 0.13 b$ \\
\hline Gemmatimonadetes & Gemmatimonadaceae & $2.00 \pm 0.04 \mathrm{a}$ & $1.31 \pm 0.05 c$ & $1.64 \pm 0.10 \mathrm{~b}$ \\
\hline Proteobacteria & Rhodospirillaceae & $1.66 \pm 0.08 \mathrm{~b}$ & $1.97 \pm 0.04 \mathrm{ab}$ & $2.59 \pm 0.17 \mathrm{a}$ \\
\hline Proteobacteria & Sinobacteraceae & $2.04 \pm 0.08 \mathrm{a}$ & $2.11 \pm 0.22 \mathrm{a}$ & $1.37 \pm 0.12 b$ \\
\hline Verrucomicrobia & Pedosphaeraceae & $2.31 \pm 0.33 \mathrm{a}$ & $1.65 \pm 0.05 b$ & $8.68 \pm 0.28 \mathrm{a}$ \\
\hline
\end{tabular}

Means ( \pm standard error) in each phylum or family followed by similar letter are not significantly different based on the least significant difference (LSD) test at the $5 \%$ probability level.

A total of 10 abundant families (relative abundance $>2 \%$ ) were identified (Table 9). Rubrobacteraceae represented a range of percentage from $6.09 \%$ (cereal field) to $8.68 \%$ (grass-covered vineyard) of the total sequences, followed by Bradyrhizobiaceae (2.33-2.78\%) and Bacillaceae (1.23-2.10\%). Bacillaceae and Solirubrobacteraceae were $2.10 \%$ and $2.56 \%$ in the cherry farm, and $2.02 \%$ and $2.42 \%$ in the grass-covered vineyard, respectively, which were significantly higher than those percentages in the cereal field (1.23 and 1.78\%, respectively). The relative abundance of Gemmataceae, Gemmatimonadaceae, Sinobacteraceae, and Pedosphaeraceae were also significantly influenced by the cherry farm system. In opposite, the highest abundance of Chitinophagaceae and Rhodospirillaceae were obtained from the samples of the grass-covered vineyard, which was significantly higher than the corresponding abundances in other fields.

At the genus level, the majority of bacteria among all fields belonged to the genera Rubrobacter, Bacillus, Gemmatimonas, Gemmata, Steroidobacter, and Pedosphaera (Figure 3). Cluster analysis showed that the bacterial community composition of the cherry farm and grass-covered vineyard clustered into one group, with a distance of $2.53 \%$, which was separated from the cereal field (Figure 3 ). 


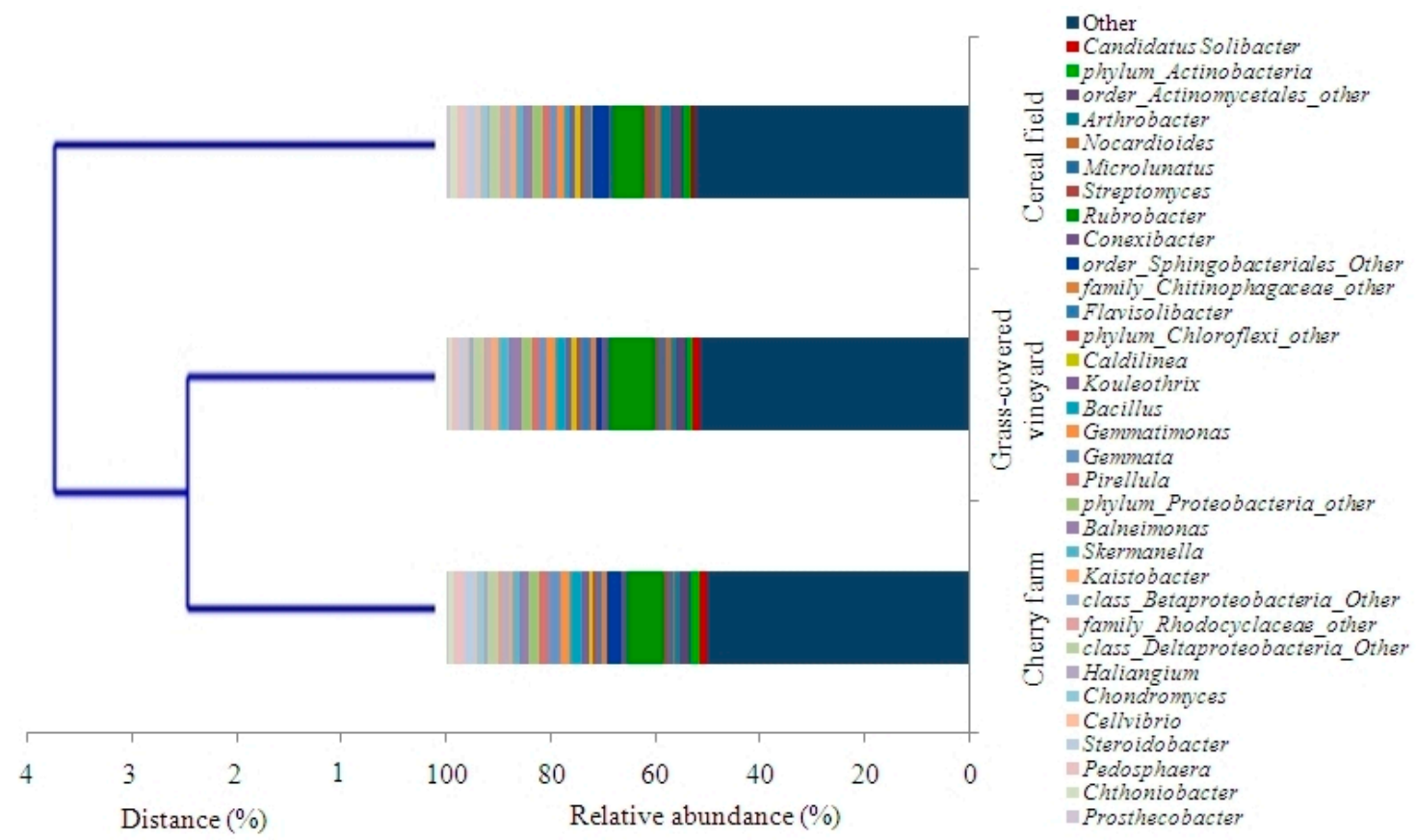

Figure 3. Analysis (Ward's method) of the 16S rRNA composition of soil bacterial communities at the genera level.

\section{Discussion}

Our results showed that the SOM, MBC, and BSR were highest in the topsoil of the grass-covered vineyard. The increase in the SOM amount in these soil samples was likely due to a mix of different reasons, some of them already demonstrated by other authors, namely, the type of cropping systems and tillage intensity, e.g., the reduction of soil disturbance through no-tillage [31], the management of crop residues [32], and of cover crops [33], both practices increasing the plant inputs returned to the soil. In fact, crops' shoot and root biomass of cover crops and grape trees were left on the field, in contrast with the cereal field and cherry farm, where residue removal and crop harvesting decreased organic inputs. These findings are in agreement with Ramesh et al. [34], who found a considerable impact of land use changes on SOC and reported that chemical and biochemical soil parameters were constant under low-intensity farming practices. A similar finding was also reported by Safaei et al. [35] who showed that the SOM and soil quality in natural ecosystems were considerably affected by land uses. Increasing $\mathrm{MBC}$ is the consequence of high-concentration $C$ substrates available to the soil microbial communities [36] and of a significant positive trend in the quantity of organic $C$ in the natural or low-disturbance ecosystems over the long run [12], such as the grass-covered vineyard in the present research. Similarly, an increase in MBC has already been found with decreased levels of human activities i.e., no-tillage practices [37] and straw returning [38] by changing the soil physicochemical environment, such as soil water content, porosity, and bulk density.

According to the results, the rankings were grass-covered vineyard $>$ cherry field $>$ cereal field for BSR, and cherry farm > grass-covered vineyard > cereal field for CSR. This means that the microbial respiration was increased by higher organic $C$ inputs to the soil from crop residue management in the grass-covered vineyard. On the other hand, soil respiration and microbial activity are strongly influenced by soil water content [39]. Therefore, in the present study, lower rates of basal and cumulative respiration in the cereal field as compared to others may be explained by dry land farming and lower water content.

The ranking for CUE was cherry field > cereal field > grass-covered vineyard. CUE is a principal parameter used to estimate soil $C$ dynamics and to understand the destiny of $C$ resources by partitioning organic $\mathrm{C}$ between $\mathrm{MBC}$ and mineralized $\mathrm{CO}_{2}$ [25]. In the cherry farm, higher CUE indicated an increased decomposition, resulting in reduction of plant and microbial organic matter in soil [40]. 
The highest amounts of metabolic quotient $\left(\mathrm{qCO}_{2}\right)$ were detected in grass-covered vineyard $(0.058$

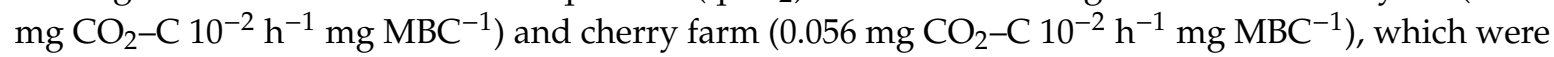
about 16 and $12 \%$ higher than that in cereal field. It has been reported that stress conditions may cause an increment in the $\mathrm{qCO}_{2}$ which is related to a microbial stress, while low $\mathrm{qCO}_{2}$ may indicate more desirable conditions for microbial survival and more carbon available for biomass production [41]. High $\mathrm{qCO}_{2}$ values could also be related to changes in the bacterial-to-fungal ratio [42]. In this regard, Nsabimana et al. [43] determined $\mathrm{qCO}_{2}$ and CUE parameters to illustrate how the soil microbial activity and community composition were affected by land uses. In addition, we also found statistically significant differences among land uses in term of carbon mineralization quotient (qM). These values varied from $0.91 \%$ in the cereal field to $1.66 \%$ in the cherry farm, meaning that the cherry farm had better microbial C metabolism efficiency [44]. Lower amounts of qM in the cereal field than that in other ecosystems are related to lower ratios of easily mineralizable organic matter to stable organic matter in the soil [24].

There were statistically significant relationships between microbial respiration rate and the time period of incubation as cubic equation models. These results are also in agreement with Birge [45] who reported that the microbial respiration rate declined over the course of the incubation due to lack of organic $C$ resource. Dungait et al. [46] suggested that the availability of soil organic $C$ to microbial decomposers is one of the main factors that can influence and limit microbial respiration. This hypothesis has been supported by Birge [45] who stated that the SOM availability, and not the microbial biomass content, could limit the respiration rate.

Our results showed that the highest value of BFI was obtained from grass-covered vineyard. It has been previously reported that soil fertility is proportional to the soil microbial activity and SOM, as well as altering environmental conditions and land uses [47,48]. It has also been proved that crop residues and cover crops increase soil microbial biomass and activity and improve SOC sequestration in the long-term [49]. Therefore, cover crop residues stimulated cumulative carbon mineralization and improved SOC cycling in vineyard ecosystem, resulting in high level of BFI. In fact, grass-covered vineyard, being a more conservative system, has a large potential to improve total carbon storage in soil, given the organic input and the lower soil disturbance from tillage operations. On the other hand, BFI score in cereal field was lower than that in other land uses. This was very likely due to the frequent tillage practices and the removal of crop residues from the field, as well as to the dryland farming that can lead to a low soil biological fertility. These findings highlight the need for proper sustainable land management to prevent soil degradation [50], since the sustainability of the dryland ecosystem and its agricultural production depends strongly on proper and effective land-use and management [51]. Thus, it is quite clear that the conventional tillage with the crop-fallow system should be avoided in dryland cropping systems because of consequently reduced soil fertility and degraded chemical properties [52].

According to the evaluation by multiple linear regressions, SOM and CSR seem to be more useful to predict the BFI under different land uses. Similar results were presented by Renzi et al. [13], who found that the BFI had a significant relationship with SOM, CSR, MBC, and BSR, and increased linearly with all composing variables except for $\mathrm{qM}$ and $\mathrm{qCO}_{2}$, and particularly that $\mathrm{MBC}$ and CSR were the most important parameters contributing to the BFI.

The amounts of extracted nucleic acid were affected by different land use intensities, too. A similar finding was reported by Agnieszka et al. [53], who demonstrated that the soil DNA content was significantly influenced by land uses. It is well recognized that the soil DNA concentration is higher in soils with higher soil organic carbon [40,54]; in this regard, we found a significant positive correlation between changes in the nucleic acid concentration and SOM and MBC in soils under different land uses. Other authors reported a strong correlation between microbial biomass carbon and extracted DNA in soil [53], this relationship being affected by land use intensity and clearly indicating that microbial ecophysiology can be directly linked to soil carbon storage potential [40]. 
The composition of the soil bacterial communities in the cereal ecosystem, a management characterized by a higher disturbance and lower values of biochemical and microbiological parameters, shifted to species with a higher number of $16 \mathrm{~S}$ rRNA gene copies. It has been reported that the rRNA gene copy numbers are linked to the bacterial life strategy [55], basically classified into two main categories, copiotrophic and oligotrophic, according to their response to resource availability and life strategies [56]. Therefore, higher ribosomal RNA copy numbers detected in the cereal field than that in other land uses, as indicated by the qPCR assay, indicate an increase in fast-growing r-strategists' taxa (copiotrophic species), due to decreased microbial respiration [55,57].

Bioinformatics analyses of the $16 \mathrm{~S}$ sequencing data completely matched with the rRNA gene copy numbers. Accordingly, the abundance of oligotrophic bacterial groups (25.52\% Actinobacteria, $3.45 \%$ Firmicutes, and 1.38\%Acidobacteria) was higher in the grass-covered vineyard, while the rRNA gene copy numbers were lower than for other land uses. Oppositely, the cereal field had the highest abundance of copiotrophic bacteria (29.29\% Proteobacteria and $8.82 \%$ Bacteroidetes) which was 10.8 and $28.2 \%$ more than grass-covered vineyard and 11.0 and $11.6 \%$ higher than cherry farm, respectively. The adaptive capacities of these species permit a successful competition with other bacterial groups, particularly when the levels of soil disturbance or tillage intensity are higher. In the cereal field, we hypothesize that soil disturbance repressed microbial respiration by favoring $r$-strategists' taxa with faster growth rates and limited capabilities to degrade recalcitrant organic matter, as indicated by a significant negative correlation between rRNA copy number and soil microbial basal as well as cumulative respiration.

CHAO1, Shannon and Simpson diversity indices indicated that the whole bacterial communities were very similar, no matter the land use intensities. This finding has already been proved by many authors [58-60], who reported that there was no effect of land use and agricultural practices on the diversity indices tested (e.g., CHAO1 and Shannon). Our research supports the hypothesis that different land uses do not change species richness and heterogeneity, although significant differences in some bacterial groups were found, very likely because of the high microbial resilience and/or resistance [61].

The results of Pearson correlation coefficients agree with the results of Renzi et al. [13], who found a significant relationship between SOM and MBC, BSR and $\mathrm{qCO}_{2}$, and CSR and $\mathrm{qM}(p<0.001)$ based on Pearson correlation analyses. Similarly, Li et al. [62] and Malik et al. [40] reported that the SOM significantly correlated with MBC in different land use. It has also been reported that soil microbial communities were affected by quality and quantity of soil organic carbon [38]. Van Wesemael et al. [41] reported that the high $\mathrm{qCO}_{2}$ values represent the high energy required to keep up the microbial biomass and indicate a stressful condition for microbial communities. As a result, $\mathrm{qCO}_{2}$ values are reduced if the MBC content increases and vice versa.

\section{Conclusions}

As far as we know, this is the first study focusing on the effects of land uses intensities on both bacterial communities and biological fertility index in soil cropped in Southern Italy, a typical Mediterranean region. The number of bacterial gene abundances was negatively regulated by soil microbial respiration. As indicated by qPCR and sequencing analyses, different land uses altered bacterial abundance and community structure; in particular, copiotrophic bacterial groups in the grass-covered vineyard decreased, while oligotrophic bacterial taxa increased along with a conservative managing of crop residues and no-tillage. In addition, the determination of SOM and microbial activity parameters allowed deriving relevant conclusions about the effect of land use intensities on the three studied ecosystems. The grass-covered vineyard demonstrated the highest amount of SOM and MBC, while respiration activity, qM, and CUE were higher in the cherry farm. The BFI indicated a higher soil biological fertility in the grass-covered vineyard, which can be reasonably assumed by the preservation of this ecosystem, with none or lower disturbance. These results could be useful to farmers in decisions about the best practices to avoid or reduce the negative impacts of land use intensities. Thus, the BFI could be an effective indicator system in the perceptions and assessment of 
soil fertility. More in-depth studies could validate the results of the present research under changing climate conditions and agro-ecosystems and allow the use of the biological fertility index to assess soil quality in agricultural soils.

Author Contributions: Conceptualization: M.Y.K. and C.C.; methodology: M.Y.K., P.M., and S.S.; software: M.Y.K.; validation: C.C.; formal analysis: M.Y.K. and C.C.; investigation: M.Y.K., P.M., and S.S.; resources: C.C.; data curation: M.Y.K. and C.C.; writing — original draft preparation: M.Y.K. and C.C.; writing—review and editing: C.C.; visualization: C.C.; supervision: C.C.; project administration: M.Y.K.; funding acquisition: M.Y.K. and C.C.

Funding: This research was funded by Global Doc project-CUP H96J17000160002-financed by Regione Puglia, Italy.

Acknowledgments: The authors thank Matteo Spagnuolo and Mr. Nicola Carella for scientific and technical assistance, respectively.

Conflicts of Interest: The authors declare no conflict of interest.

\section{References}

1. Cerdà, A.; Hooke, J.; Romero-Diaz, A.; Montanarella, L.; Lavee, H. Soil erosion on Mediterranean type-ecosystems. Land Degrad. Dev. 2010, 21, 71-74. [CrossRef]

2. Shelef, O.; Stavi, I.; Zdruli, P.; Rachmilevitch, S. Land use change, a case study from southern Italy: General implications for agricultural subsidy policies. Land Degrad. Dev. 2014, 27, 868-870. [CrossRef]

3. Zdruli, P.; Calabrese, J.; Ladisa, G.A.O. Impacts of land cover change on soil quality of manmade soils cultivated with table grapes in the Apulia Region of south-eastern Italy. Catena 2014, 121, 13-21. [CrossRef]

4. Bai, X.Y.; Wang, S.J.; Xiong, K.N. Assessing spatial-temporal evolution processes of karst rocky desertification land: Indications for restoration strategies. Land Degrad. Dev. 2013, 24, 47-56. [CrossRef]

5. Bajocco, S.; Smiraglia, D.; Scaglione, M.; Raparelli, E.; Salvati, L. Exploring the role of land degradation on agricultural land use change dynamics. Sci. Total Environ. 2018, 636, 1373-1381. [CrossRef]

6. Masciopinto, C.; De Giglio, O.; Scrascia, M.; Fortunato, F.; La Rosa, G.; Suffredini, E.; Pazzani, C.; Prato, R.; Montagna, M.T. Human health risk assessment for the occurrence of enteric viruses in drinking water from wells: Role of flood runoff injections. Sci. Total Environ. 2019, 666, 559-571. [CrossRef]

7. Zdruli, P. Land resources of the Mediterranean: Status, pressures, trends and impacts on future regional development. Land Degrad. Dev. 2014, 25, 373-384. [CrossRef]

8. Lindtner, P.; Gömöryová, E.; Gömöry, D.; Stašiov, S.; Kubovčík, V. Development of physico-chemical and biological soil properties on the European ground squirrel mounds. Geoderma 2019, 339, 85-93. [CrossRef]

9. Pepper, I.L.; Brusseau, M.L. Physical-chemical characteristics of soils and the subsurface. Environ. Pollut. Sci. 2019, 9-22. [CrossRef]

10. Juhos, K.; Czigany, S.; Madarasz, B.; Ladanyi, M. Interpretation of soil quality indicators for land suitability assessment-A multivariate approach for Central European arable soils. Ecol. Indic. 2019, 99, 261-272. [CrossRef]

11. Li, P.; Shi, K.; Wang, Y.; Kong, D.; Liu, T.; Jiao, J.; Liu, M.; Li, H.; Hu, F. Soil quality assessment of wheat-maize cropping system with different productivities in China: Establishing a minimum data set. Soil Tillage Res. 2019, 190, 31-40. [CrossRef]

12. Francaviglia, R.; Renzi, G.; Ledda, L.; Benedetti, A. Organic carbon pools and soil biological fertility are affected by land use intensity in Mediterranean ecosystems of Sardinia, Italy. Sci. Total Environ. 2017, 599-600, 789-796. [CrossRef] [PubMed]

13. Renzi, G.; Canfora, L.; Salvati, L.; Benedetti, A. Validation of the soil Biological Fertility Index (BFI) using a multidimensional statistical approach: A country-scale exercise. Catena 2017, 149, 294-299. [CrossRef]

14. Laudicina, V.A.; Novara, A.; Barbera, V.; Egli, M.; Badalucco, L. Long-term tillage and cropping system effects on chemical and biochemical characteristics of soil organic matter in a Mediterranean semiarid environment. Land Degrad. Dev. 2015, 26, 45-53. [CrossRef]

15. Soleimani, A.; Hosseini, S.M.; MassahBavani, A.R.; Jafari, M.; Francaviglia, R. Influence of land use and land cover change on soil organic carbon and microbial activity in the forests of northern Iran. Catena 2019, 177, 227-237. [CrossRef] 
16. Ahmed, I.U.; Mengistie, H.K.; Godbold, D.L.; Sanden, H. Soil moisture integrates the influence of land-use and season on soil microbial community composition in the Ethiopian highlands. Appl. Soil Ecol. 2019, 135, 85-90. [CrossRef]

17. Kome, G.; Enang, R.; Yerima, B.; Lontsi, M. Models relating soil pH measurements in $\mathrm{H}_{2} \mathrm{O}, \mathrm{KCl}$ and $\mathrm{CaCl}_{2}$ for volcanic ash soils of Cameroon. Geoderma Reg. 2018, 14, e00185. [CrossRef]

18. Soil Survey Staff. Soil Survey Laboratory Information Manual; Soil Survey Investigations Report No. 45, Version 2.0.; USDA-Natural Resources Conservation Service: Washington, DC, USA, 2011.

19. Walkley, A.; Black, I.A. An examination of the Degtjareff method for determining soil organic matter, and a proposed modification of the chromic acid titration method. Soil Sci. 1934, 37, 29-38. [CrossRef]

20. Martínez, J.M.; Galantini, J.; Duval, M.; López, F.; Iglesias, J. Estimating soil organic carbon in Mollisols and its particle-size fractions by loss-on-ignition in the semiarid and semi humid Argentinean Pampas. Geoderma Reg. 2018, 12, 49-55. [CrossRef]

21. Vance, E.D.; Brookes, P.C.; Jenkinson, D.S. An extraction method for measuring soil microbial biomass C. Soil Biol. Biochem. 1987, 9, 703-707. [CrossRef]

22. Isermeyer, H. EineeinfacheMethodezurBestimmung der Bodenatmung und der KarbonateimBoden. J. Plant. Nutr. Soil Sci. 1952, 56, 26-38.

23. Liu, X.; RezaeiRashti, M.; Dougall, A.; Esfandbod, M.; van Zwieten, L.; Chen, C. Subsoil application of compost improved sugarcane yield through enhanced supply and cycling of soil labile organic carbon and nitrogen in an acidic soil at tropical Australia. Soil Tillage Res. 2018, 180, 73-81. [CrossRef]

24. Mganga, K.Z.; Razavi, B.S.; Kuzyakov, Y. Land use affects soil biochemical properties in Mt. Kilimanjaro region. Catena 2016, 141, 22-29. [CrossRef]

25. Geyer, K.; Dijkstra, P.; Sinsabaugh, R.; Frey, S. Clarifying the interpretation of carbon use efficiency in soil through methods comparison. Soil Biol. Biochem. 2019, 128, 79-88. [CrossRef]

26. Herlemann, D.P.R.; Labrenz, M.; Juergens, K.; Bertilsson, S.; Waniek, J.J.; Anderrson, A.F. Transition in bacterial communities along the $2000 \mathrm{~km}$ salinity gradient of the Baltic Sea. ISME J. 2011, 5, 1571-1579. [CrossRef] [PubMed]

27. Pascazio, S.; Crecchio, C.; Scagliola, M.; Mininni, A.N.; Dichio, B.; Xiloyannis, C.; Sofo, A. Microbial-based soil quality indicators in irrigated and rainfed soil portions of Mediterranean olive and peach orchards under sustainable management. Agric. Water Manag. 2018, 195, 172-179. [CrossRef]

28. Martin-Didonet, C.C.G.; Chubatsu, L.S.; Souza, E.M.; Kleina, M.; Rego, F.G.M.; Rigo, L.U.; Yates, M.G.; Pedrosa, F.O. Genome structure of the Genus Azospirillum. J. Bacteriol. 2000, 182, 4113-4116. [CrossRef]

29. Wallenstein, M.D.; Vilgalys, R.J. Quantitative analyses of nitrogen cycling genes in soils. Pedobiologia 2005, 49, 665-672. [CrossRef]

30. Kuczynski, J.; Stombaugh, J.; Walters, W.A.; González, A.; Caporaso, J.G.; Knight, R. Using QIIME to analyze 16S rRNA gene sequences from microbial communities. Curr. Protoc. Biol. 2011, 27. [CrossRef]

31. Jat, H.; Datta, A.; Choudhary, M.; Yadav, A.; Choudhary, V.; Sharma, P.; Gathala, M.; Jat, M.; McDonald, A. Effects of tillage, crop establishment and diversification on soil organic carbon, aggregation, aggregate associated carbon and productivity in cereal systems of semi-arid Northwest India. Soil Tillage Res. 2019, 190, 128-138. [CrossRef]

32. Qiu, Q.; Wu, L.; Li, B. Crop residue-derived dissolved organic matter accelerates the decomposition of native soil organic carbon in a temperate agricultural ecosystem. Acta Ecol.Sinica. 2019, 39, 69-76. [CrossRef]

33. Novara, A.; Minacapilli, M.; Santoro, A.; Rodrigo-Comino, J.; Carrubba, A.; Sarno, M.; Venezia, G.; Gristina, L. Real cover crops contribution to soil organic carbon sequestration in sloping vineyard. Sci. Total Environ. 2019, 652, 300-306. [CrossRef] [PubMed]

34. Ramesh, T.; Bolan, N.; Kirkham, M.; Wijesekara, H.; Kanchikerimath, M.; Srinivasa Rao, C.; Sandeep, S.; Rinklebe, J.; Ok, Y.; Choudhury, B.; et al. Soil organic carbon dynamics: Impact of land use changes and management practices: A review. Adv. Agron. 2019. [CrossRef]

35. Safaei, M.; Bashari, H.; Mosaddeghi, M.; Jafari, R. Assessing the impacts of land use and land cover changes on soil functions using landscape function analysis and soil quality indicators in semi-arid natural ecosystems. Catena 2019, 177, 260-271. [CrossRef]

36. Fujita, K.; Miyabara, Y.; Kunito, T. Microbial biomass and ecoenzymaticstoichiometries vary in response to nutrient availability in an arable soil. Eur. J. Soil Biol. 2019, 91, 1-8. [CrossRef] 
37. Denardin, L.; Carmona, F.; Veloso, M.; Martins, A.; Freitas, T.; Carlos, F.; Marcolin, É.; Camargo, F.; Anghinoni, I. No-tillage increases irrigated rice yield through soil quality improvement along time. Soil Tillage Res. 2019, 186, 64-69. [CrossRef]

38. Hao, M.; Hu, H.; Liu, Z.; Dong, Q.; Sun, K.; Feng, Y.; Li, G.; Ning, T. Shifts in microbial community and carbon sequestration in farmland soil under long-term conservation tillage and straw returning. Appl. Soil Ecol. 2019, 136, 43-54. [CrossRef]

39. González-Ubierna, S.; Lai, R. Modelling the effects of climate factors on soil respiration across Mediterranean ecosystems. J. Arid Environ. 2019. [CrossRef]

40. Malik, A.A.; Puissant, J.; Buckeridge, K.M.; Goodall, T.; Jehmlich, N.; Chowdhuty, S.; Gweon, H.S.; Peyton, J.M.; Mason, K.E.; Agtmaal, M.V.; et al. Land use driven change in soil $\mathrm{pH}$ affects microbial carbon cycling processes. Nat. Commun. 2018, 9, 3591. [CrossRef]

41. Van Wesemael, B.; Chartin, C.; Wiesmeier, M.; von Lützow, M.; Hobley, E.; Carnol, M.; Krüger, I.; Campion, M.; Roisin, C.; Hennart, S.; et al. An indicator for organic matter dynamics in temperate agricultural soils. Agric. Ecosyst. Environ. 2019, 274, 62-75. [CrossRef]

42. Nannipieri, P.; Ascher, J.; Ceccherini, M.; Landi, L.; Pietramellara, G.; Renella, G. Microbial diversity and soil functions. Eur.J. Soil Sci. 2003, 54, 655-670. [CrossRef]

43. Nsabimana, D.; Haynes, R.J.; Wallis, F.M. Size, activity and catabolic diversity of the soil microbial biomass as affected by land use. Appl. Soil Ecol. 2004, 26, 81-92. [CrossRef]

44. Mocali, S.; Paffetti, D.; Emiliani, G.; Benedetti, A.; Fani, R. Diversity of heterotrophic aerobic cultivable microbial communities of soils treated with fumigants and dynamics of metabolic, microbial, and mineralization quotients. Biol. Fertil. Soils. 2008, 44, 557-569. [CrossRef]

45. Birge, H.E. What Happens During Soil Incubation? Exploring Microbial Biomass, Carbon AVAILABILITY and temperature Constraints on Soil Respiration. Master's Thesis, Colorado State University, Fort Collins, CO, USA, 2013.

46. Dungait, J.A.; Hopkins, D.W.; Gregory, A.S.; Whitmore, A.P. Soil organic matter turnover is governed by accessibility not recalcitrance. Glob. Chang. Biol. 2012, 18, 1781-1796. [CrossRef]

47. Basso, F.; Bove, E.; Dumontet, S.; Ferrara, A.; Pisante, M.; Quaranta, G.; Taberner, M. Evaluating environmental sensitivity at the basin scale through the use of geographic information systems and remote sensed data: An example covering the Agri basin (southern Italy). Catena 2000, 40, 19-35. [CrossRef]

48. Willy, D.; Muyanga, M.; Mbuvi, J.; Jayne, T. The effect of land use change on soil fertility parameters in densely populated areas of Kenya. Geoderma 2019, 343, 254-262. [CrossRef] [PubMed]

49. Ghimire, B.; Ghimire, R.; VanLeeuwen, D.; Mesbah, A. Cover crop residue amount and quality effects on soil organic carbon mineralization. Sustainability 2017, 9, 2316. [CrossRef]

50. Papini, R.; Valboa, G.; Favilli, F.; L'Abate, G. Influence of land use on organic carbon pool and chemical properties of VerticCambisols in central and southern Italy. Agric. Ecosyst. Environ. 2011, 140, 68-79. [CrossRef]

51. Wang, J.; Liu, G.; Zhang, C.; Wang, G.; Fang, L.; Cui, Y. Higher temporal turnover of soil fungi than bacteria during long-term secondary succession in a semiarid abandoned farmland. Soil Tillage Res. 2019, 194, 104305. [CrossRef]

52. Sainju, U.M.; Lenssen, A.W.; Allen, B.L.; Stevens, W.B.; Jabro, J.D. Nitrogen balance in response to dryland crop rotations and cultural practices. Agric. Ecosyst. Environ. 2016, 233, 25-32. [CrossRef]

53. Agnieszka, W.; Zofia, S.; Aleksandra, B.; Artur, B. Evaluation of factors influencing the biomass of soil microorganisms and DNA content. Open J. Soil Sci. 2012, 2, 64-69. [CrossRef]

54. Kallenbach, C.M.; Frey, S.D.; Grandy, A.S. Direct evidence for microbialderived soil organic matter formation and its ecophysiological controls. Nat. Commun. 2016, 7, 13630. [CrossRef] [PubMed]

55. Männistö, M.; Ganzert, L.; Tiirola, M.; Haggblom, M.M.; Stark, S. Do shifts in life strategies explain microbial community responses to increasing nitrogen in tundra soil? Soil Biol. Biochem. 2016, 96, 216-228. [CrossRef]

56. Fierer, N.; Bradford, M.A.; Jackson, R.B. Toward an ecological classification of soil bacteria. Ecology 2007, 88, 354-1364. [CrossRef]

57. Fontaine, S.; Mariotti, A.; Abbadie, L. The priming effect of organic matter: A question of microbial competition? Soil Biol. Biochem. 2003, 35, 837-843. [CrossRef] 
58. Jiang, X.; Wright, A.L.; Wang, X.; Liang, F. Tillage-induced changes in fungal and bacterial biomass associated with soil aggregates: A long-term field study in a subtropical rice soil in China. Appl. Soil Ecol. 2011, 48, 168-173. [CrossRef]

59. Nazaries, L.; Tottey, W.; Robinson, L.; Khachane, A.; Abu-al-Soud, W.; Sorensen, S.; Singh, B.K. Shifts in the microbial community structure explain the response of soil respiration to land-use change but not to climate warming. Soil Biol. Biochem. 2015, 89, 123-134. [CrossRef]

60. Navarro-Noya, Y.E.; Gómez-Acata, S.; Montoya-Ciriaco, N.; Rojas-Valdez, A.; Suárez-Arriaga, M.C.; Valenzuela-Encinas, S.; Jiménez-Bueno, N.; Verhulst, N.; Govaerts, B.; Dendooven, L. Relative impacts of tillage, residue management and crop-rotation on soil bacterial communities in a semi-arid agroecosystem. Soil Biol. Biochem. 2013, 65, 86-95. [CrossRef]

61. Rincon-Florez, V.A.; Clement, N.G.; Dang, Y.; Schenk, P.M.; Carvalhais, L.C. Short-term impact of an occasional tillage on microbial communities in a Vertosol after 43 years of no-tillage or conventional tillage. Eur. J. Soil Biol. 2016, 74, 32-38. [CrossRef]

62. Li, J.; Wu, X.; Gebremikael, M.T.; Wu, H.; Cai, D. Response of soil organic carbon fractions, microbial community composition and carbon mineralization to high-input fertilizer practices under an intensive agricultural system. PLoS ONE 2018, 13, e0195144. [CrossRef]

(C) 2019 by the authors. Licensee MDPI, Basel, Switzerland. This article is an open access article distributed under the terms and conditions of the Creative Commons Attribution (CC BY) license (http://creativecommons.org/licenses/by/4.0/). 